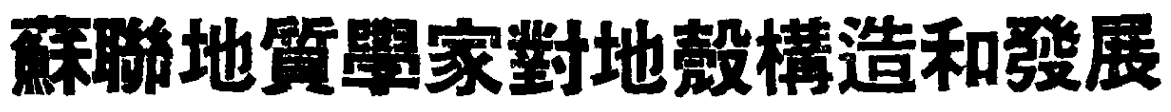 問題的見解
}

\author{
石 延 漢 \\ （南京大
}

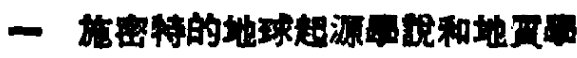

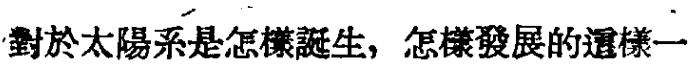
调千百萬人關心的重要問題，独联科學家近年來 提出了一些柿新的假設，其中最獲得學者們公認 的 O. . 施密特院士的假設。这固然是一倜天文 祭的問題, 但是作第太陽系行星之一的地球的起 源和發展的問題，自然也應該包括在內，所以施 密特的理論必然也率涉到地球物理學、地球化學 和地質學的問題。就地質學來講, 我們了解比較 清楚的，祇是地球墢展的最後五萬萬年光景的暦 史。但是䢐最後一段的厢史也必然被决定於地球 以及太陽系婈展的總進程。因此，施密特理諭所 指示的總發展方向也勢必應該䆓穿於地質時期主

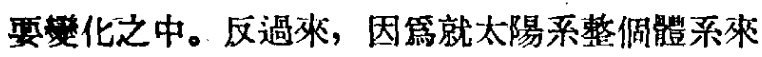
說, 砈有在地球上、在地球的地質時代中, 我們 的知識比䡈詳細、比較精確, 所以, 天文學上的 施密特理論和地質學問題的合理聯系，是驗登施 密特理諭的最重要的低搌。

簡單地說, 施密特的理論是這樣的：當原始 太陽一一當時没有繞它旋轉的行星系統一一緋銀 河系中心族轉的時候, 可能會俘獲了位於銀河本 面上的隕星體的雲蓩一一這是一個非常低温的氣 體和固體質點的集合。以後這做集合便跟着太陽 運動，而且繞太陽旋轉，逐濑凝聚而成做别的行 星。行星的“肧芽”原是非常冷的, 但是, 當逗些 冰凍“泼芽”逐漸長大以後, 內部逐渐有熱量積聚,

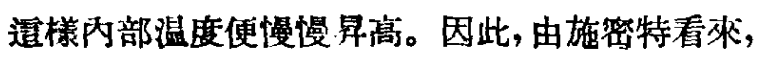
就行星一一地球也是如此一一的總的器展方向來 講, 是由冷紸熱的。這和一切關於太陽系以及地
球糜史的古典看法, 以第一切是由熱愁冾的看法, 恰好相反。施泌特的理諭是非常富有革命性的。

施密特用通樣一個革命性的假没, 不㒖定性 地而且也定量地說明了太陽矛畨啮的許多特點。

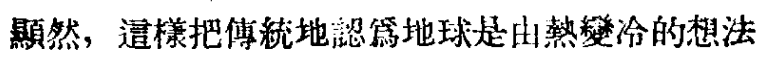
反過隶溜篇是由冷戀熱的見解, 也必須從地質學 上找到理論上的往合。假如說, 從新的觀點重新 來觀察奔部地質上闕於地球發展進程的事賽, 發 現不谨施密特的學說可以完善地解燡一切, 而且 一切事筫甚至迫使我們不得不承涊地球的確是由 冷變熱的，因此，可以有把握地說施泌特的學份 得到了最有力的㤢證。蘇聯學者門像 5. . . 列文、

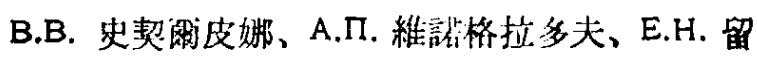
斯季赫、 П.H. 克鲁泡特金、B.B. 别洛烏䕀大等等

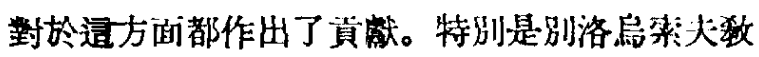
授全面地考虑了地球發展的總進程, 提比了極合

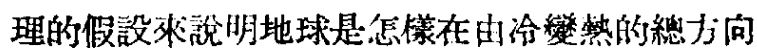
中逐潮發展, 在蘇聯“白然”雜誌 1951 年第 9 期及 1952 年第 2 期望速續發表了兩篇文慞, 說明了他

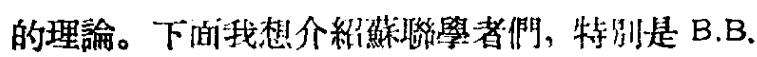

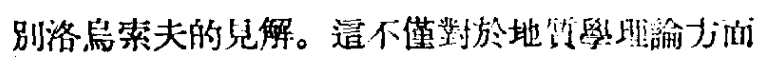

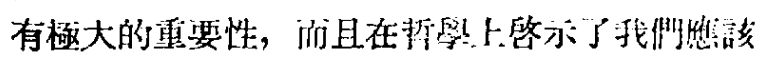

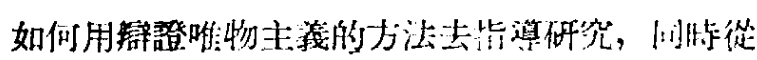

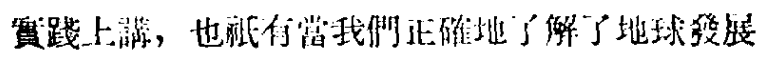

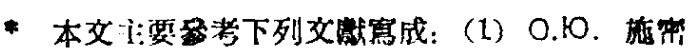

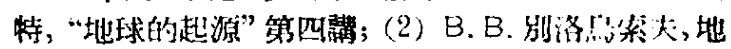

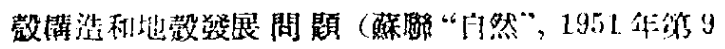

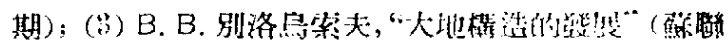

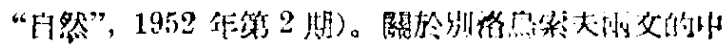

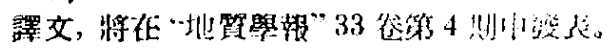
科學嗔 㪕
195 分作 
規律以後, 才可以了解岩曆在地款中分仍的規 律, 因而才可以正確地指導我們在什筑地方去尋 找我們所需要的有用矌應。

馬克思、列䆞主義的思想方法, 装求我們在 科學研究上要從事實出發, 而不是從假想出忽。 的有當我們全面地認識了主要事筫以後, 最後發 現一切事惯可以合理地被包含在一㑑理論或假設

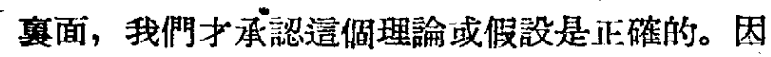
此我下面想逐潮列舉泏各個事實（並且篇了醒目 起見, 將事筫安排上次序明確地陳述出隶), 然後 展開討論, 看所有的事嘪如何问能梳一在施密特 的由冷變熱和别洛烏索夫對於地殸變動的理論之 中。所將要列舉出來的事實必然應該包括地球的 密度、內部分啳、地殻上海陸分作的美異和一切 地史上所䌦柲的地䡰變動。

\section{二 地球內的物程分佈}

我們從地球上的精密重力測量, 求出了地球 上的重力值 $g=981$ 圆䊉/ ${ }^{2}$; 另一方面根據 大地 測量, 可以求出地球的平均牛徑 $a=6,371$ 公里, 那窊根據萬有引力, $g=k^{2} \frac{M}{a^{2}}$ ( $k^{2}$ 是萬有引力 “常數), 可以求出地球的總質量 $M$ 和地球的平均 密度 $\rho$ 來。結果 $\rho=5.5145$ 克/ 凰米 ${ }^{3}$ 。也就是說比 重（和同體積水的重力之比）是 5.5 倍。對於其 他的行星, 我們得用別的方法來求平均密度。先 根揲天體力學求出每一倜行星的總質量, 再從天 體測量决定行星的大小, 那㦄便可以算出密度。 結果我們得知:

第一件重害:太陽系中地球的密度是

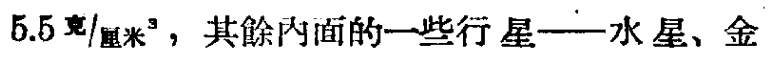
隹、火星的密度都和地球茬不多, 比水要大; 可 是外面的行星一一未星、土星、天王星和海王星， 星的體積踓大, 但是密度較小, 和水不相上下。

密度 5.5 克/原米 ${ }^{3}$ 自然僅僅是地球的平均密度, 事貫上密度必然叮以因地下深度而不同。最表面 的地殼就是我們所接觸到的岩睠, 經過值接的測 定知道它的密度僅嚾是 2.7 克/風米 ${ }^{3}$ 。那禁由此我 椚必須得出一個結論, 就是地球內部應該是由更 重的東西所組成, 洨撉面的密度要超過 10 克/風米”。 以上。咳樣可以得出

穿二件事惯: 地球內部的密度應該随地下深 度的增加面獒州。
科學通報
自然我們得淮一步問，地球究竟是由什麼東 西搆成的? 這時我們與其說注意到它的化合物的 組成， \#撑說注意各種不同的元素在地球萝是以 怎樣的比例來組成。顯然我們不可能對整偲地球 進行化學分析，但是地球化學提供了許多寥差资 料。這時更有僄优的是别的天體——行星、流星、 慧星、隕星、太陽、恒星, 甚至星雲一一的化學粗 成問題。選亶除了隕星可以直接進行化學分析以 外，其他天體的知識都是根措光就分析而來的。 種種的證據逐漸使我們相信: 各種天體所含的各 種不同元素的原子的数目的比例，大致彷彿。迶 一個結果標誌着宇宙中一切天體間的普掘聯智和 物質的一致性, 這樣我們得到重要的

第三件事整: 地球和隤星大致具有相同的化 學成分, 它們和讧的天體, 像恒星、星篹等, 除 掉較輕的元素以外, 其他重的元素, 其所含原子 數目的比例幾乎是相等的。”

但是僅僅這樣，我們的知識賟姆态概括。我

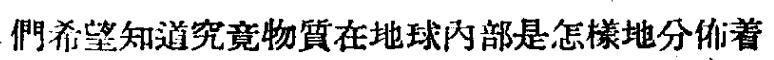

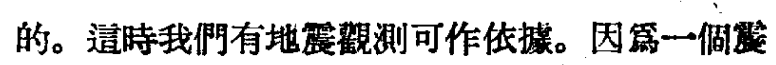
源的各種各樣的层動是穿過地球內部以後才走到

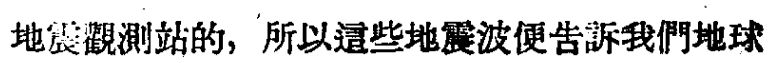
內部的消，息。我們將地震的觀測與天文及其他的 觀測配合, 可以算出地球內部的泌度分作來, 在 多少深的地方有密度等於多少的東西。精密計算 的結果, 我們發現地球分成地核和外园二屡, 在 地表下面深約 2,900 公里的地方密度從小於 6 克/盾米 ${ }^{3}$ 的物質一躍而到密度大於 9 克/圆米 ${ }^{3}$ 的物 質，所以那裹開始從外圈轉入了地核，換们話說， 地核的本徑是地球卅徑的一斗略多一點。並且因 篇地核不能使地震赛的横波通過, 所以從地震波 的傳播來講, 地核具有流體的性質。但是密度没 生不連續楼化的决不僅僅是深 2,900 公里地方一 處，别的地方尤其在表面展中我們發現有好幾個 不連續展, 因此對於地球內部物僙分佈, 我們嵒 篇

第四件事惯：地球队部物質分居你在，愈近 表酒, 分層愈細, 到了染達 2,900 公里 的內部可 能是均一的具有流體性留的地核。

地震波不僅告訴我們地球不闰深戛物翼的密 度, 而且边告訴我們它們的彈性係數是多少。如 果我們將這些數據和我們所墢㧩的許多岩石种确 
物相比較, 便叮能去推論每一首由什䓡物質所構 成。例如，我們認篇由表而到下面 1,000 公里篇 止，上面極薄的地方是主要由放鈵質所構成的伩 鋁图，底下是主要由矽鎂質所構成的矿鎂图。至 於地核則可能是鐵䤼翼所構成的。逐漸往深處起, 逐濑是更重的元素, 再加以强大础力使它掭縮, 這模便叮以了解第二件事實。

當我們研究遠處地震的時候, 我們所獲得的 是關於地球內部的一般知識, 但是如果侀究近的 地震, 我們便可了解地球最淩面展的知識, 雖然 遭些是表面底，但仍是我們不能用直接鑽探所能 觀測到的。覓然表面居的知識應該知道得更群細 些。我們現在知道

苐五件事宣：就大陸而言，從地表到以下 20 公里左右是比較酸性（会氧化的 $70 \%$ 以上）的

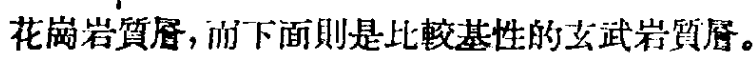

火灴對於這件事䡠提供更遖接们證㨜。現在 大陸表面蜼然一般都被花岗岩所掩蓝，但是當地

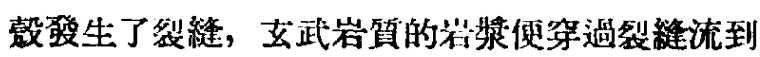
地表面柬，因篇在流出來的時候，途中美不多不 會和所遇到的岩展發生化學上的相互作用，因此 便形成了玄武岩。無諭在地質時代甚至在今天, 我們都可以看到常火川爆發時有玄武岩從深處流 出.

從第三件事暂，我們可以相信行星一一包括 地球一一和隕星是具有親虚關係的, 不過以前婄 第行星是由太陽所產生, 而隕星入是由行星所產 生的, 是某顆大行星爆裂的結果而產生很多小行 星和隕星的。但是施密特恰恰探取了相反的看法, 他認篇埕星不是由行星所产生, 相反的, 媍星倒 是比地球等行星永生得夏早的東西。當冰凍行星 肧芽逐渐形成的時候, 不断㟋生一面碎裂, 一面 凝聚的過程。隄星以及流星和小行星就是碎裂的 殘娟，而凝聚成長的過程便産生了行星。今天在 地球大氣中還可以看見流星和隕星的落下, 這表 示地球今天還在不斷藉凝聚隕星而成長之中。顯 然逪樣施嘧特的理論是能充分訟明第三件事實 的。

B.ю. 列文更仔細地推論了行星的成長過程。

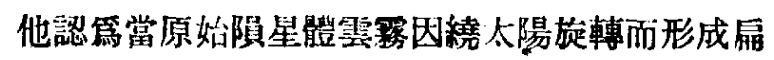

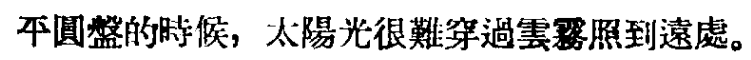
所以陮太隄校近的部分温度很高, 而較遠的地方

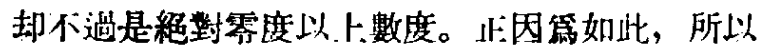

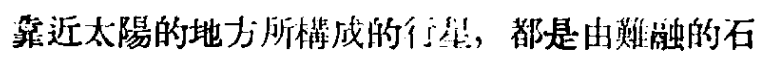
質和金濁物質所構成，而一些輕的氣體，如氫、

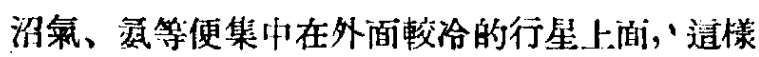
第一件事實便獲得简單的镜明。第二件事貝中， 地球所以比別種天體較少有签的元素, 亦不難了 解。

一倜最有舆趣的問題是地球的年龄究竞有多

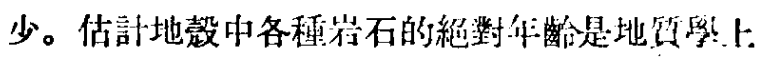

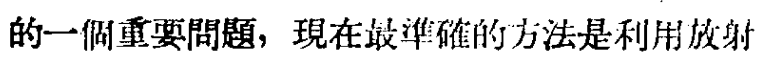
性元素。例如，鈾鿌子是一倠放射性元素。這種 元素的原子核會自動地破裂，放什各種柆子-和能

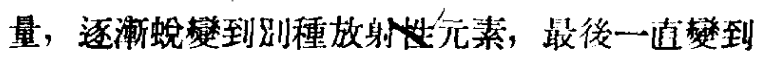
鉛, 就停止不怕戀了。多數的鈾原子如何變成鉛 原子，其變化速卒的规律我們是知逆的。那标假 定一塊岩石生成之初, 只含有鈾而不含有鈆, 多 少年以後有些鈾原子縟战鉛了，有些低然是銅 (這

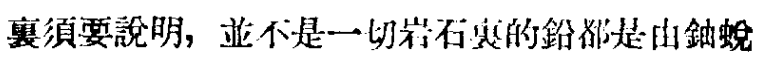

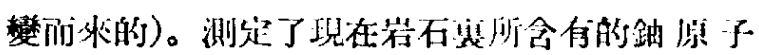
數和鉛原子數, 便不蜼冰壮运熄岩石生成的年代

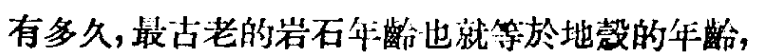
我們現在公涊

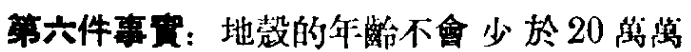
年。

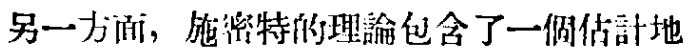

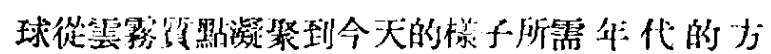

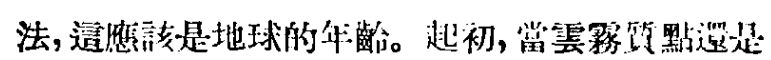

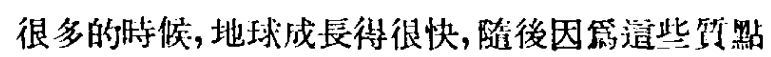
减少, 成長的速湾也就減少, 到了今天, 成長的 速度已經很慢很慢。今天從行星際空間這有院只 和流星落下, 大致相紧於等 24 小時落下 50-100 萬顿，這也就是今天地球成会的速度。如果我們 能够求出地球成長的定量關係, 那束不難求出地 球在生成後多少年㭙, 其成長速率是多少; 施泌 特就根據他的理論, 求壮地球生成後的年代 $T$ 和 那個年代的成是速率 $\triangle$ 閔的緊係如下式:

$$
A T=-\frac{1}{3} \log \frac{\Delta}{3 A m_{T}}+\frac{1}{2} \log 3+\frac{1}{\sqrt{3}} \frac{\pi}{6}
$$

式中的 $m_{T}$ 是年代 $T$ 時的地球質量, $A$ 則是 一湖和地球牛徑及原始雲霧有關的常數。那末

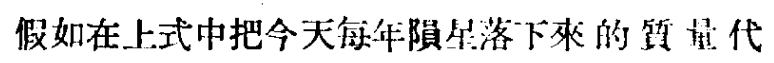

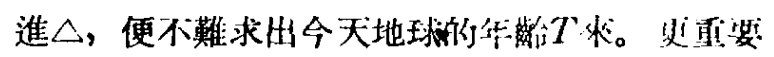


的, 是 $\triangle$ 出現在 $\log$ 的後面, 所以 $\triangle$ 的佔計稍微 美一點, 並不過分影響於 $T$ 的大小。具體求解的 結果， $T$ 大概是 60 萬萬年。這個數㨡是 地 球全 䌡的年龄, 顯然它應該比地嗀的年齢老一些。這 樣, 施密特的理論定量地說明了第六件事實。 但是如果施密特的假設說地球是由冷變熱的 話, 必須說明第什公會由冾變熱的。因爫一個位 於星際空間的星體不断會失熱而冷却, 所以由熟 紮冷是很易首肯的。假如要說由冷變熱的話, 是 由接近於絕對零度綎成今天甚至像火山一樣使岩 石都融揢的高温的話, 必須提出來這倜能量的源 泉是什㦄。在這裹我們要再度提到放射性元素。

地球裹的放射性元素除了铀的系統以外, 還 有鈳鈾、釬以及鉡的系統。鉡一般不是放射性的，
但是那個原子量等於 40 的鉡是放射性的，它的 放射性不强, 可是因篇地球裹鉀的量比鈾等要及 得多, 因此它的總熱量也就很可觀。僅僅根譃地 表的岩石, 可以估計出全地表中所含有的放射性 元素的熱量來。但是造還不過是在今天道侗時代

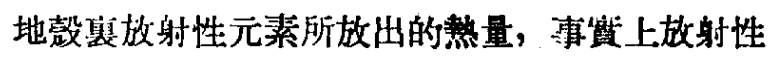
元素是在遂漸蛻督成安定元素的。如果某一時候 的放射性元素原子數是 $Q$ 。經過時間 $t$ 以後, 硋 元素的原子數是 $Q$, 則 $Q=Q_{0} e^{-\lambda t}$ ，假如在後來 地球質量不太弶更的話, 以前的放射性原子數崤 該是遠多於今天放射性原子數的。下面是全地球 上各種放射性元素在現在及過去年代中熱量嫚生 （卡/小時）的估計:

\begin{tabular}{|c|c|c|c|c|}
\hline & 現 & 20 萬 萬 年 前 & 30 萬 萬 年 前 & 40 萬 莕年 前 \\
\hline 銷 & $21.26 \times 10^{10}$ & $2942 \times 10^{16}$ & $34.06 \times 10^{10}$ & $39.03 \times 10^{24}$ \\
\hline 蚰鈾 & $0.89 \times 10^{10}$ & $6.33 \times 10^{10}$ & $17.34 \times 10^{10}$ & $43.43 \times 10^{10}$ \\
\hline 针 & $20.27 \times 10^{16}$ & $22.78 \times 10^{10}$ & $24.12 \times 10^{18}$ & $25.13 \times 10^{56}$ \\
\hline 鉀 & $4.70 \times 10^{18}$ & $19.46 \times 10^{10}$ & $79.53 \times 10^{18}$ & $80.42 \times 10^{10}$ \\
\hline 總 & $47.12 \times 10^{10}$ & $77.99 \times 10^{18}$ & $115.05 \times 10^{16}$ & $188.01 \times 10^{16}$ \\
\hline
\end{tabular}

（根㨜 B.P.赫洛的堡算）

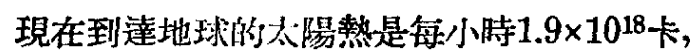
我們可以看出來 40 庽萬年以前放射能的熱量已和 太陽熱相當。正因篇這個放射能的熱量在地球內 部的積萫，才使地球內部的温度景高到幾千度。

同時, 因䉆我們發現一般的愈是古老的岩石 所含的放射性物質少，造使我們歸結到

第七件事實：放射性元素有不斷向地表上星 集中的超向。

但是我們必須知道, 放射性元素向地表的集 中不是到處一律的, 有的地方多些, 有的地方少 些。此較集中的地方, 便使岩漿流出而成火山。 火山的分佈辀然是集中在特殊一些地方的, 正好 明地下融婃的不過是一些局部地景温中心, 而 並没有要求地球內部全體都在融熔狀態的必要。 逜一個显温是局部的而不是全面的見解，在我們 後面的叙逝中異常重要。

\section{三大陸和深洋}

地球表面是凹凸不平的, 並且顯然有一個明 㙷的高度分界線把地表面分成高低兩種水淮面, 高的水淮面是陸地和淺海, 我們以後概稱大陸, 而低的水淮面則是深洋, 大陸和樑洋的分界線就 是所謂海水下酒的大陸坡而不是陸地和淺海分界 的海岸線。但是地貿學的證據證明大陸和深洋的 位置閣係在我們所熟知的地質年代裹决不是固定 不變的。把海底地庴和陸地地層比較㸴究結果, 我們發現在近代大陸上自從古生代以來一直到今 天篇止，從來沒有發現過任何一塊崔石可以證明 是形成於洋底深處的。另一方面，我們也確筫知 道在今天的洋底地方過去曾經存在 過大陸。例 如, 太平洋邊界的一些內海, 如白令海、鄂萑荻 克海、日本海、中國東旅、南海、馬隶莘島等是 在第三紀甚至第四紀北新形成的。另外在太平洋 的彼岸、大西洋和印度洋都是如此。由此對於地 豰發展我們獲得了很重要的

第八件事菑：原始時代大陸面積 此現在更 
大, 甚至可能連一塊坬立的大洋都炈有, 海洋是 到了後來甫逐形成的。

更做得注意的是洋底和大陸的岩居的美異。 我們没有法淔㨄查洋底地質，但是從薏洋傅 過來的地震却提供我們很多的知識。我們已䌈確 定在太平洋的中央部分完全没有花崗岩詹，而在

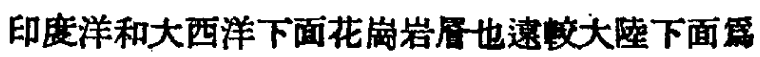

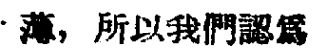

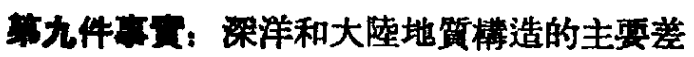
異，是後者爫厚數十公里的花崗岩圈所權成，可 是前者却第玄武岩圈所構成。

顯然，在我們解㔍海洋和大陸起源運䇐一㑑 重要問題上，第八件和第九件事家將是極重要的 線慗。

現在如果我們認篇是因篇故射能在地表集中

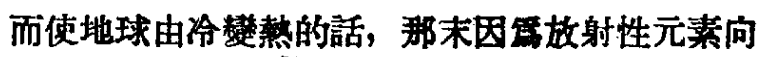
地表的接近是不均匀的，所以有的地方地下年温 多些，有的地方开温少些，甚至有的地方由於地 熱向外迅速傳導出去的結果，合使得地款下面的 㖷域冷却，或者至少阻碍了它的昇温。别洛烏慗 夫把连叫做相對冾却過程, 而且特别指出㯰個相 對冷却過程和陳嚄的地球的紹對收縮的說法毫無 相同之處。因筬地敚下面虽域的相對冷却是不均 匀的，所以也引起了地彀的個别部分的也是相對 的和不均匀的沉降, 結果便形成了海洋低地, 而

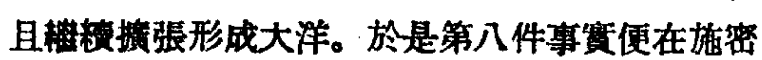
特假設的前提下獲得了合理的說明。至於海陸下 面地辰性質的不同造件事實，要待後面问明了花 闹岩的形成過程以後，才可能給以合理的解釋。

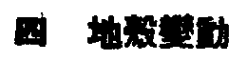

地数决示是永薏處於静止狀態，恰恰相反，

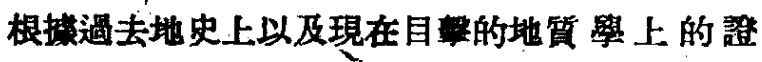

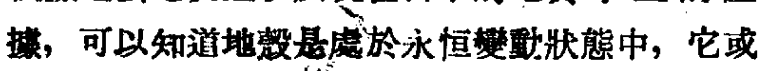
者是全面而総愎的非長久年代難以學察的變化， 或者是像火山地震等爆䜤性的激烈雙動, 我們把 它們總稱岔地謷變動。

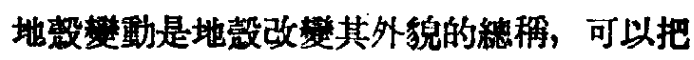
它分成四倜類型:（1）地殻升降運動, 以某部分

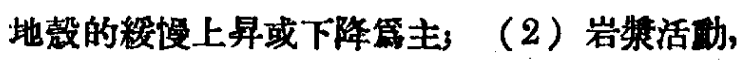
指岩䈋或者沿着裂楗流出地面變成揢岩, 或者在

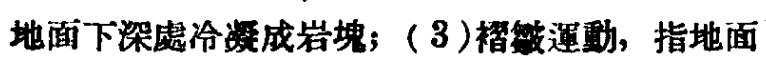

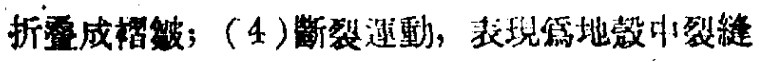
的形成, 不间部分發生了相對移勒。仆降洷動和

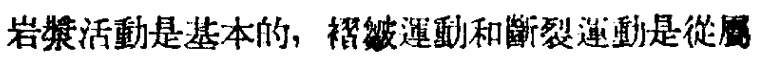
的、派生的現解。

篇了追湖在過去地翼時代檁的㺪降进動發生

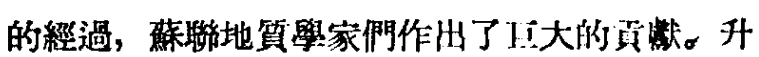

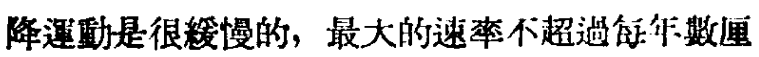
米。當地豰在大區域內沉降的時候, 便會形成了 水品——例如海。這時便有物質沉皘㺫海底; 觀 測證明在近代大陸地方上面的海踶, 其海低沉陷 下去的速率和海底上.沉皘物堆積的速 率大致相 當; 結果沉皘物的堆積抵消了海底的沉陷, 所以 沉積物的厚度踓可蓬數公里, 而海水的哚度却不 過數百公尺。根據造倜說法, 便叮以把不问地質 年代的沉積物的厚度看成是沉陷的深度, 斻運樣, 蘇聯大地構造學者們便發現了過去地微开降過程 的全部歷史, 並且找出了極重要的規律。他們沽篇

如十件事基：根據升降速動，可以把大陸地

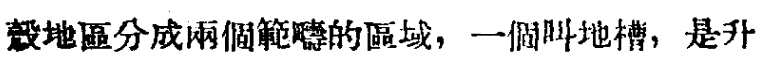

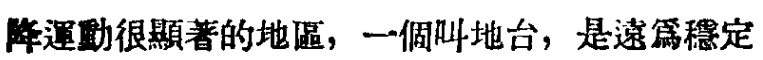
的地區。

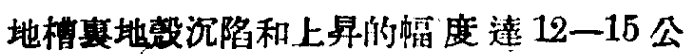
里, 而且升降的對比很明顯, 在比校涨小地榅尖鈆 地對立着隆起和沉降, 而且造些地带形似狄長的 情圆, 寛數十公里, 但長度却達數百公里。其他三 種地殸運動在道裏也很活躍。相反，在地分裹， 上升和下降的幅度不過數百乃至數十公人, 個別 隆起和沉降都具圆形, 而且比地槽的平降地區要 大, 直徑達数百乃至數千公里, 因此對比很不䫏

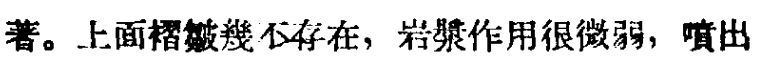
岩的成分很均匀, 都是玄武岩翼, 可是地梢中的 噴出岩則其成分從酸性到基性，委化很多。

但是地槽和地台的區分在時間上講, 決不是 一成不弶的。地質歴史告訴我們在太古代㙨乎整 倜地球都是地槽, 到處地款楼動都很强烈, 後桃 在元古代內才出現了最初的绞小的地台。這嵄随 着時間的進展, 在地槽变逐濑出現了新的地台, 地台又逐漸擴張, 地槽則相對地縮小。換们話說, 地槽地台们時閒變化主要是

第十一件事曾: 地台的生成要比地槽承得 遲, 地槽随時閒的進展轉變成地台, 到今天地台 已比地槽佔有更大的面積。 
但是，逜是地款缶動在時間上的一個單方向 的總進程，地槽縮小，地台演大，可是除了這個 單方向的進程而外，還有一個基本上周而復始的 反覆循環變化，所以可以按照每個周期分成個别 的地殸變動的階段。我們知道得最清楚的是地督 整整 20 萬萬年的歷史中最後 $1 / 4$, 就是 5 萬萬年: 中的情况。這其間我們劃分䈧三個階段，就是克 里東期、赫爾辛期和阿爾星斯期, 每個階段相當 15,000 萬年光景。克里東期包括寒武 紀 和 志留 紀，赫爾辛期包括汁盆紀、石炭紀和二叠紀，而 阿爾卑.斯期包括整個中生代和新生代。每一個階 段中的周期性的反覆，總的說起來是這核的。

第十二件事的: 每一個周期無論就地槽來講, 或者就地台來講，在前牛個階段在大陸上主要是 地殻的沉陷，因此海水便進入到陸地上來。而在 後牛個階段則主要是地款的上景, 於是陸地的部 分便撗張，海也就相對地縮小。

地槽在前牛個階段中主要是下降, 祀剩下個 别高起的島煌，所以其情况正如今天的馬來翠島 一䓇, 而且富有火山活動的无其是海底的火山, 嗢 出的揢岩最初具有玄武岩質的成分, 到了後來便 出現了中性的和酸性的聺㞸; 沉陷的速率達每年 數毫米，因篇整個時期要趠續數千萬年，所以地 殸沉陷的總幅度便涬 10-15 公里。大陸沉降的結 果, 便發生海侵。可是到了後牛個階段, 便在以 前强生過最强烈下沉地方新生出了隆起, 因此座 生了地形的倒轉: 在海的低地長出了山胍, 而許 多前牛個階段中的隆起地帶却全部或者局 部 沉 陷。因雼後牛個階段主要是隆起，所以原來的海 䟖成了海峽，再解體成湖泊，終而至於完全乾 涸,一方面自然同時形成了山胍。在前牛個階段顯 得比較微弱的槢够斷裂運動也在後牛個階段裹顯 得活躍, 岩摮侵入而形成了大塊的花崗岩體, 到 了最末期, 岩漿沿着裂繾上仆, 在裂綎中洽凝結 晶而構成裂縫侵入岩和岩脈, 最後甚至形成了地 面火山。地槽睃褶䏢的巨大隆起和沉陷，分别稱 篇背科地和向斜地。

至於地台，歌多資本主䔐國家的地質學家認 偏是完全“死亡”的部分，但是事蕒是：它們在一 個地款委動階段中也依然有緩慢的震湯運動, 而 且在前卅個階段主要是沉降, 後牛個階段主要是 隆起, 自然這種朴降的區域遠較在地槽睃要大,
形成了凸地和凹地。例如波释的海地学是前者的 例子，而莫斯科流域是後者的例子。

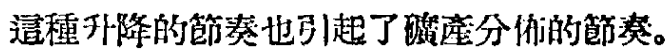
例如, 煤多半形成在前牛個階段和後牛偑階段間 的轉折期, 石油也同樣, 不過因営它的可動性, 可能移動得相當遠。其弡現地區則多牛在地槽的 向斜地裹，相反在地槽背斜地裹，則主要出現有

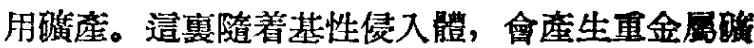
林一一䤼、鉻、鉑、鐵等，而花鹃岩岩基、裂䋖 侵入岩和岩脈帶來了金、銅、銀、鉬、獡、 錫、銻、手等等。

但是對於地湸變動的單向性進程一一由地槽 戀成地台，以及週期性進程一一沉隔和隆起的交 替，都不應該看成是死板的。就週期性進程來說， 先沉陷後隆起不過是總的傾向，事望上在總的升 降週期中又算插了各種低級的升降運動。圖 1 表

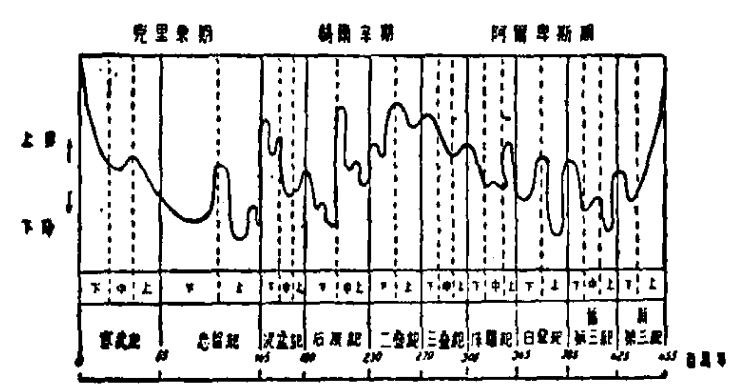

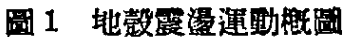

示在三㑬地殸變動階段裹地殻升降的概圖，可以 看出在總震盪週期上又重叠了别的升降運動。共 次就單向性的進程來馀，地槽縮小，地台撗展， 確是總的方向。圖 2 表示在三個階段中地台如何 成長，地槽如何縮小的情景。但是就個别地區個

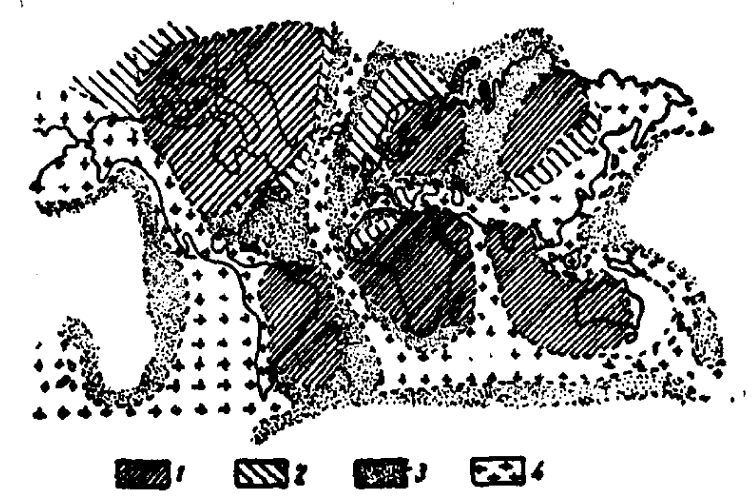

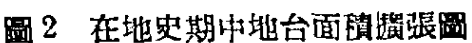

1一克里果期的地台; 2一赫爾华期開 始時地合的成层; 3- 阿雨界斯期開始 的成長，4-阿爾卑斯期的地槽。 
别時間來說, 也会經看到相反的進程, 就是

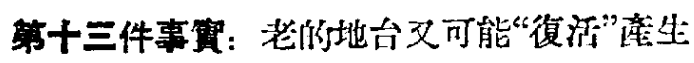
了和地槽相類似们運動。

例如，中亞細亞從古生代中期或末期，便一 直是地台, 地朊運動很微弱, 但是從第三紀的中

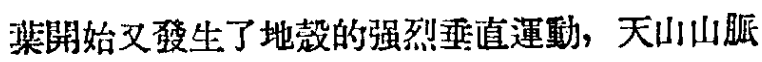
和盆地便是這榡形成的。這種現象的出現恰好可 以駁倒那些資產階級的學者們所倡導的所謂 “地 球不久便將死亡”的唯心觀點。

當我們䟽観了地款變動的情况之後，我們便 可以對於第五件事货一大陸表面是花崗岩而下 面是玄武岩一獲得初步的說明。因第火山揢岩 大部分是玄武岩, 道正好馀明地款表面下有着很 深厚的玄武岩質居，當它沿着裂縫上仆的時候， 不會和途中岩居疆生相互作用, 所以流出來便是 玄武岩。但是地㪍下面的玄武岩居可以因第向待 後面說明的作用, 墢生了厚化過程。在一個地款 玟動階段的初期，流出來的是玄武岩質熔岩，但 是在前牛個階段的末期便出現了密度較小的中性 和酸性的揢岩。通種熔岩在地豰變動的後牛储階 段中，因第主要是上升運動，所以便在大的呕力

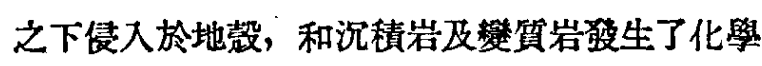
作用, 於是引起了適常的條件, 使它經成了花㘣 岩, 我們稱之篇花菵岩化。

因第地改最初全是地槽，地槽中的上升部分 和下降部分不断變更它們的位置，所以終於在大 陸的表面形成了花岗岩圈。第五件事實就是逜嵄 馀明的。

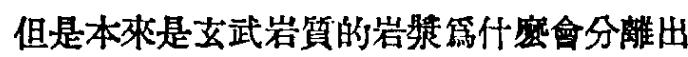
中性或酸性的岩摮來呢? 又必須問, 地改所以會

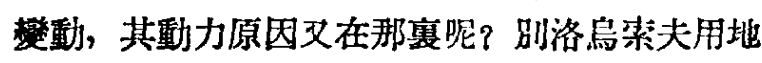
下岩等中的分化作用答覆了㯰些問題, 並且合理 地說明了䚺多事㗨。(見第五節)

還有, 所有地款變動規律是以大陸的觀測第 基礎而建立起來的, 但是深洋底下是怎樣呢? 近 代的研究證明了।

第十四件事素: 深洋底裹也有地槽和地台存 在, 其關係和大陸上一樣。

数於造點, 我們祣要舉一些例子便行了。中 大西洋春是和阿爾缶斯及高加等一樣在阿爾午斯 期末期從地槽上朴起來的海底山眽。中印度洋春 也是如此。在遭些得的雨侧, 洋底都是地台, 和

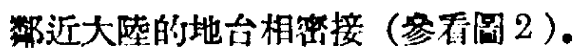

\section{五 分化作用的梅念}

顯然, 更進一步的更基本的祝明必須從地球 內部去器售。

因篇在每一個地裻等重乃階段的最初期和最末 期涌出來的岩漿是基性的玄武出，而在造一階段 的前牛期終了乃至後牛期中, 出來的是密度較小

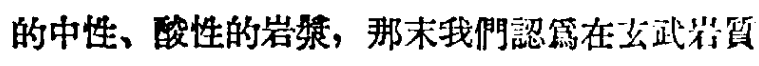

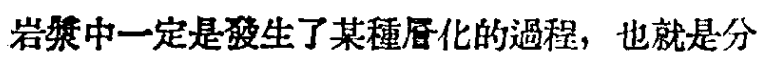
化作用，於是在玄武岩辰的表面, 集皘了而暧因 而也是更爯酸性的成分. 既然造種情洗今天還在

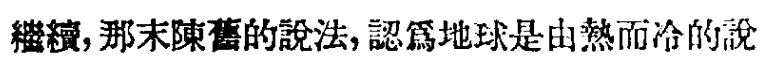
洗便是不能接受的了。因䉆如果是那樣的話, 队 部物筫的后化應該很早在地筫時代便已經完畢。 事筫躰然恰恰相反，那末便迫使我們探取相 反 的, 就是地球是由冷樊熱的假定, 施密特的理論 正提供了造樣一倜假定。因篇這個理諭說, 由冾 的固體犋點構成的行星內部的分化作用應呟進行 得綏慢而悠久。譄樣地犋學和天文學在逼亶互相 結合起來了。

可是進一步必須問：什等是分化作用的條

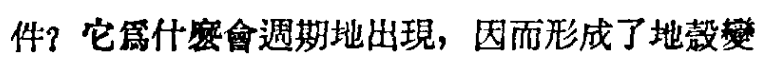
動的各階段？它篇什在不同地方不同地出現， 因而形成了地槽和地台?

最初曾經認第這個分化作用僅僅是力學的分 化, 重者下沉, 輕者上浮, 但是這是不安當的。 因第社有當密度各異的構成部分在足够大的坮體 的時候, 祇是當它們是可塑性的時候, 才可以㡎 生純力學的分化作用。可是我們沒有理由認雼地 球原始是密度各罣的大的物體所構成的, 相反, 施密特的理論認䍃是由隕星體質點所構成的溶液 或微細分散的均与混合物。其次重力分化文和第 七件事寞相達背, 因第放射性元素是重元素, 但 是它却違背了重力而浮上来。

假如溶液或微細分散的均匀混合物間所發生 的分化作用不是力學的話, 那末它便㤫該是熱力 學的了。也就是說, 礁該把它常作一個物理化學 體系來看待。這樣一個體系的平衡, 是取冯於系 的成分, 也取决於系中物質的性質，闹時也取决

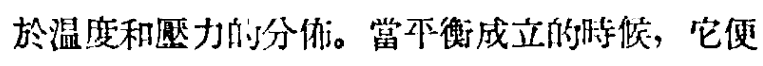
是玄武岩質岩愳，可是如果上逃任何一個條件變 
動了一下，非衙便被破壊，便獾生了分化作用，

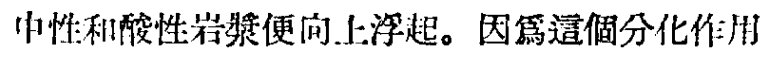
是有條件的, 有時保持平衡, 而有時又會發生分

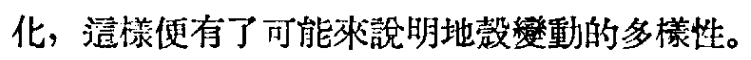

媓然這種分化作用不是純力學的, 所以當平 衡破壞發生分化時, 重的放射性元素因篇和輕的 氧化物間的地球化學關係便也上搨, 造樣難以理 解的籍七件事䠝便獾得說明。

要精確汁算地球內部情况的熱力學平衡及平 衡破壞的情况自然不是一件容易的事。據概略的 佔計, 首先證明在地球重力場下所成立的平衡, 必須是銔、鎂和鐵的含量應該隨染度而愈增; 因 第地球在唇久時間之後, 基本上應該成立平衡, 那末造就表示了今天地球內部的物質分佈, 而追 正是前进第二件事䨘所要求的。但是平衡的成 立, 祀能就地球全體整個說起來大致是如此, 至 於個别地區個别時間隨時會因第佟件的䊼化而破 壤了本衡, 於是便發生了分化作用, 地球內部的 物質也就發生了水平和喠直的移動, 這特在地球 表面上便表現第地款變動。那末，什寉條件會促 使物質分化，什㦄條件又會反過來增强其均匀性 呢? 假如物質成分没有變化附話, 温度和壓力降 低便會引起分化, 温度和医力的鼠敲便會促淮均 匀化。假如物質成分同時變化, 情况便更複雜。

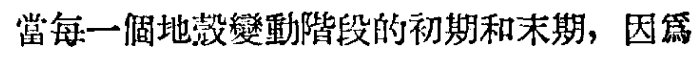
流出來的是玄武岩, 這說明這時地球內部成立了 整時的平衡。但是當地槽地款開始下沉, 地球內 部壓力温度發生變化, 平衡便破壞, 發生分化, 使輕的酸性岩漿上浮, 又因放射性元素一同上 升, 形成了局部早?温中心而膨脹, 使地殸上升, 這時酸性岩漿便传入地殻中去, 這樣便生成了花

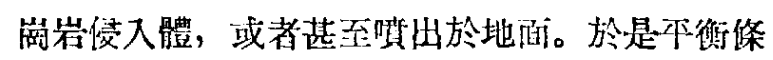
件又再度成立, 岩漿又變成均匀的立正岩筫, 因 而一個媐期便終了。蘇聯的地質學家們就這樣用 分化作用說明了地殻變動的階段變化的第十二件 事實。

這種平衡和分化的看法, 自然不僅適用於地 球內的較上㞕, 而且也一定可以適用於地球更深 的內部, 不過更深的地方, 便更不利於分化, 這 是因篇: 第一、永到地球內部, 黏性也就愈增 加, 第二、地球物理學證明, 忞到地球內部, 重 力會減少 (它最後漸䖯於零)。因此, 翁到內部,
必然物筫就愈均匀, 遭正是前㿟第四件事蜜所强 調的。

前面說過, 逜個平衡是熱力學系絰的平衙, 而不是純重力平衡, 所以遭正可以說明我們早就 觀测到的

第十五件事地：地殸重力均匀的條件在地球 各處並不完全䈣格地成立。

例如, 大高加素山便是焦荷過重, 而且它的 近代隆起, 是抗逆着地款均衡力陑發生的, 另一 面在吘多大洋上却是負荷不足。不過繃的說起 來, 地陪上到處大致是成立重力均衡的。這正說 明了一件事: 地球內部平衡條件的决定, 重力是 一個最基本的因子, 但不是唯一的因子。

到了逐裹, 别洛鳥奖头引進一個新的概念, 使理論向前更弡展了一步。他說, 雖然分化作用 是地球的一般現缘, 但是因篇不同深處條件的各 異, 我們可以認雼在不同深處會墢生不同的分化 作用, 它們之閏互相獨立; 換句話說, 地球內部 的分化作用是分别許多展次進行的。如前所远, 愈到內部, 忞不利於分化作用, 那末我們可以結 論說: 上面居次的分化作用, 應該進行得快些, 下面展次的分化作用，應該進行得慢些。

現在這樣假定: 表面詹的分化作用引起了地 槽上的地汸變動, 而梁居的分化作用引起了地台 的地殻變動。既然表面厚的分化作用是淮行得較 快的, 所以其上升、沉降比較激烈, 而且因篇是 表面的現象, 那末一定會在狭小地區內形成很陡

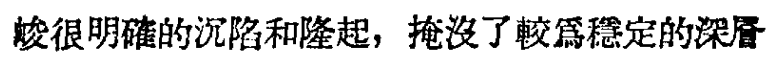
過程的影響。可是深厚的過程, 一定是綏慢而稳 定地進行, 所以地台便分成平綏而穞定的凸地和 凹地。遶樣第十件事惯所表示的地椣和地台的特 點便不難了解。

當地球最初形成的時候, 表面的分化作用進 行得很普遍, 所以自然掩没了深厓的過程, 於是 當時地球到處都是地槽。但是物質在一定佟件下 的分曆能力並非無穹盡的, 痋早它會衰竭。而且 進行得快些的上尾的分化作用一定骍竭得快些, 當局部地方分化作用衰竭了的時候, 造地方便不 再是地槽, 這時候梁㕆作用便㙷露出來了, 於是 正像第十一件事賽所說的一㥞, 地槽逐漸䉆地台 所替代。

可是我們說，如果深原作用夏是引起地台妾 
的地数䌘動的話, 那末踓說表面原的强烈作用會 掩沟住深居作用, 所以在地槽中很難辨認深屋影 零, 但是如果把地槽和地台連起乘考察, 一定會 看理深后影響固然可在地台上表現成凸地和凹 地, 但譄個梁居影響在地槽的很深下面一定也是 作用着的, 所以它們應該會從地台向地槽連續過 去。因此我們會看到

第十六件事赏: 地台裹的凸地和风地並不同 限於地台衰, 它椚㗂該延繶到地槽之內去。

毁測的結果證明確是道樣。像 H.C. 沙茨基 所指出的一樣: 俄羅斯地台的“下玻伏爾奇”凹地 向南延伸到裹海區, 而且一直通到高加索地區。西

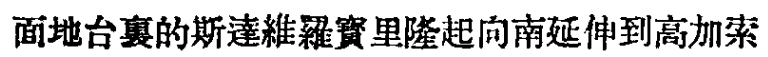

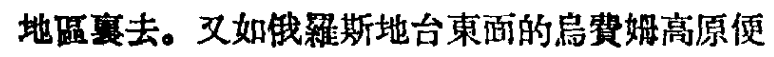
越過地台界限順緯線横切地槽裹的烏拉爾儿脈。

远楼的事费, 除了用分化作用的多居次性來

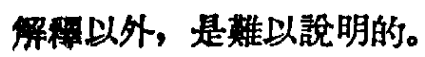

而且，也祗有利用了多底次性的概念，才可以 欲明地台的復活 (第十三件事宽)。多层次性 踓 然主張各居次之間的多少獨立性, 但是我們汰洺 有任何理由可以說各居次間絕對互相坬立, 極不 相于, 相反的必然會相互影響。當上居的分化作 用業已停止, 地槽委成了地台以後, 因篇更梁展

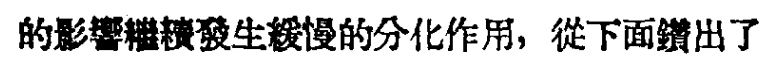
若干物算到上居去, 於是委面了上居的成分。通

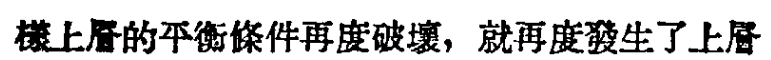
的分化作用, 在地台意便突然灭出現了升降猛烈 的地数受動。

最後，我門提一提深洋底面的問題。傯前面 所䚺的一漛, 深洋的形成是起因於所謂相對冷却 過程, 而地槽和地台却是起因於上展和深居的分 化作用, 而且分化作用是在地球整個規模中墢生 的, 所以正像第十四件事筫所指出來來的一樣, 地 棈和地台是睡分別出現於大陸, 也也分別出現於海 洋的。

那末, 怎様来說明第九件事賽, 就是洋底下

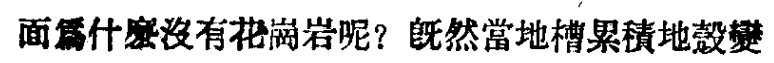
趿的綃果, 會使地款篇花厥岩所掩蓋, 而且, 洋
底也有地樯的話, 那末便没有理由欲明何以洋低

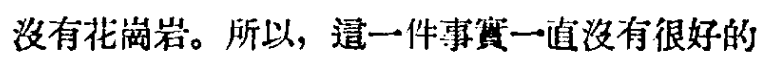
解釋。然而分化作用却使我們合理地說明了它。一 既然有許多大陸在中生代末期方沉降到海洋中去 的, 那末照我們的說法, 在未沉陷到海洋中去以 前, 它上面應該是有花岗崖岩的。換句話說, 我椚 必須承認: 生成了的花厥岩是掌地款沉降下去的 時候, 才再度消隇的。我們記得: 花崖岩是立武

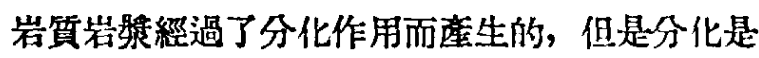
起因於熱力學平衡條件的破壤，那末我們可以碩 料選倜分化作用是一個可逆的過程。就是說, 药

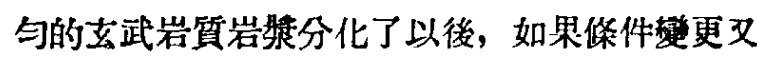
會可逆地再攀成均匀的溶液。所以，當大陸沉降 下去變成洋底的時候, 花南岩居被裂䋖所破墙, 被大量的去武岩眼所異第，重新被玄武岩流所掩 蓋, 最後花厥岩的“殘餘”便又逆轉地溶化到玄武 岩寒去了, 這就是今天洋底没有花崗岩的說明。

這㥞, 我阴前後列舉了關於地款的構造和破 展的一共十六件主要事實, 而這些事筫在 0.1 . 施密特的太陽系生成理諭和 B.B. 别洛烏装夫的 地球队部多居次性的分化作用的假設中, 獾得了 完整的說明。因此,我椚不能不承認: 地球是由冾 熱熱的, 地球內部從表面到深居不断弹生着分化 作用，逻偑作用一直延䅡到今天，而且一定還會 䋹䌅到更遠的將來。地球劻正在它的青春時期。

當我們學習了落聯科學家的理論以後，我們

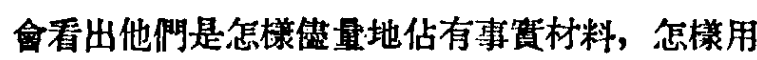

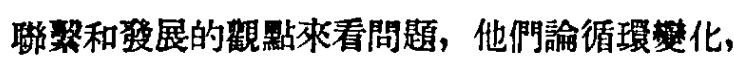
但是却不把循㻴看成是完全反致不會 滈展的進 程; 他們也論各展次的獨立性, 但是却不忘掉相 互獨立的各居次中一定會有相關性。他們也論作 用的衰竭, 但是總認清在表面的衰竭作用之外又 有更梁居更楥慢的活動, 更深的進程會使表面上 一時衰竭了的作用復活。所有通一切, 就是一個 誩證唯物主義者的思想方法和工作方法。而正因 筬追個思想方法和工作方法探帶來了今天的勝 利, 並且將會带來明天更巨大的勝利。 